\begin{tabular}{|c|c|c|}
\hline \multirow[b]{2}{*}{ II } & Int.J.Curr.Microbiol.App.Sci (2021) 10(11): 218-225 & \\
\hline & $\begin{array}{l}\text { International Journal of Current Microbiology and Applied Sciences } \\
\text { ISSN: 2319-7706 Volume } 10 \text { Number } 11 \text { (2021) } \\
\text { Journal homepage: http://www.ijcmas.com }\end{array}$ & 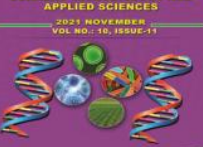 \\
\hline $\begin{array}{l}\text { EXCELLENT } \\
\text { PUBLISHERS }\end{array}$ & & \\
\hline
\end{tabular}

\title{
Determinants of Awareness of Good Agricultural Practices (GAP) Among Vegetable Growers in Punjab, India
}

\author{
Carloyne Cherotich* and Manmeet Kaur \\ Department of Extension Education, Punjab Agricultural University, \\ Ludhiana - 141004, India \\ *Corresponding author
}

Keywords

Determinants, Good Agricultural

Practices, Adoption

Article Info

Received:

06 October 2021

Accepted:

05 November 2021

Available Online:

10 November 2021

\section{A B S T R A C T}

Good Agricultural Practices (GAP) is a new idea for Punjab farmers. Most vegetable growers are unaware of it and have not implemented the practices. The study aimed to establish the factors that influence the awareness of GAP among vegetable growers in Punjab, India. Consequently, 100 vegetable growers were selected by purposive sampling and simple random sampling techniques. Multiple regression was used to analyze the effect of the variables on the awareness of GAP among the vegetable growers. Results showed that education, operational land, land leased, training, and income had a significant effect on the awareness of GAP. Based on the results, emphasis on training and capacity building of vegetable growers regarding GAP is suggested as a way of increasing awareness.

\section{Introduction}

Successful adoption of any agricultural practice needs prior awareness, but different conditions and factors may affect this. Knowledge and information of new technologies and new practices depend on socioeconomic characteristics such as age, sex, access to information, household-level characteristics, and intra-household norms (Bernier et al., 2015). Extension, level of education, family size, and training also significantly influence awareness of improved agricultural practices, such as knowledge to IPM (David and Asamoah 2011; Bernier et al., 2015).

The idea of Good Agricultural Practices (GAP) has developed in recent years in the face of a rapidly changing and globalized food economy. Good Agricultural Practices (GAP) minimizes food safety risks. However, its poor implementation along the vegetable production chain is a challenge. 
Vegetables have a high risk of contamination due to the wide use of chemicals, fertilizers and pesticides. This makes them unsafe for consumption, hence a threat to consumers and vegetable producers. Various studies reveal high usage of chemicals among Indian farmers and that few farms follow good agricultural practices (Chaturvedi and Nagpal 2003; Mehta 2005; Chaudhari et al., 2012). Consequently, regulatory institutions and enforcement systems are in place to ensure that products meet set standards and requirements (Arpita et al., 2019).

The standards and regulatory bodies for the domestic market include the Food Safety and Standards Authority of India (FSSAI) (Arpita et al., 2019). Some of the state governments have also enacted different laws towards regulation. However, despite this, vegetable quality remains a challenge and has experienced rejection, especially at export markets.

Vegetable production in Punjab covers an area of over 208 thousand hectares, and production of 168502.90 thousand metric tonnes per hectare (Anonymous 2016; Nair and Barche 2014). Different factors influence the successful production and marketing of vegetables, chief among which is their safety and quality. GAP adoption is one way of ensuring the quality standards, but its awareness within the state is low (Cherotich 2021). This study, therefore, sought to identify the determinants of awareness of GAP among the vegetable growers of Punjab State, India.

\section{Materials and Methods}

The study was conducted in Punjab State in India. An interview schedule was used to investigate the determinants that would influence the adoption of GAP among vegetable growers. The first part of the schedule captured the respondent's general information, age, education level, vegetable growing experience, farm size, income, and training. The second part was an audit checklist developed with reference to FAO and IndGAP recommendations (FAO, 2004; IndGAP, 2011), which captured farmers' awareness of GAP standards. The checklist had 151 statements categorized into 13 different sections namely: (i) site history (ii) planting material (iii)water usage (iv) fertilizers, manures, bio-solids, and nutrition (v) chemicals (plant protection or other agrochemicals) (vi) integrated pest management (IPM) (vii) soils and substrates (vii) harvesting and handling (ix) animal and pest control (x) worker health and safety (xi) storage and transport (xii) waste management (xii) training. Descriptive and inferential statistical analyses such as frequencies, percentages, and multiple regression were carried out to determine farmers' socioeconomic characteristics, awareness, and compliance by use of the statistical package SPSS (version 26). Awareness was measured through rating on a 3- point rating scale ranging from 2 for 'fully aware', 1 for 'partially aware', and 0 for 'not aware'.

\section{Results and Discussion}

Seven socioeconomic characteristics of the vegetable farmers were studied and presented in Table 1. The results show that the majority of the farmers $(75 \%)$ were middle-aged, over half of them $(66 \%)$ with a secondary level of education and above. Singh et al., (2017) and Mohammad et al., (2020) have also reported findings that the majority of farmers in their studies fell into the middle age groups, while Adebayo (2012) and Mohammad et al., (2020) found that most of the small scale farmers possess higher education level.

Seventy percent had low vegetable growing experience, and over two-fifths (64\%) were marginal farmers. 84 percent of the farmers 
had high income from vegetable farming, and only four percent were trained on improved vegetable production practices. Samra and Kataria (2014) have reported similar findings of higher income from vegetable cultivation among farmers in Punjab.

\section{GAP awareness among vegetable growers}

Awareness of GAP standards is presented in Table 2. The awareness score of the farmers about GAP protocols ranged from 45 to 96 against the possible range of 0 to 151 . The Data indicated that 67 percent of vegetable growers in Punjab were partially aware of site history GAP standards, findings similar to those by Waghmod et al., (2020) in their study on GAP adoption among mango farmers. Half the respondents were not aware of the standards for planting material, while a majority $(63 \%)$ were not aware of the standards needed in water usage and conservation, similar to findings by Rochelle et al., (2014) on lack of verification of water by farmers before use. Arati (2020) and Luquet et al., (2005) observed that watersaving is not a priority for most farmers since they rely on subjective judgments based only on their practical experience and observation to make decisions (Knox et al., 2012). However, this differed from a study by Rehman (2013), who found that most farmers were aware of water management practices.

The results on awareness of GAP protocols for fertilizer, manures, bio-solids, and nutrition revealed that more than half the respondents (59\%) had partial awareness of the standards and that 68 percent of the vegetable were unaware of the standards for chemicals. The findings are similar to those by Reeves and Schafer (2003) and Sandesh et al., (2021).

The majority of the vegetable growers $(64 \%)$ were highly aware of IPM GAP standards to be followed and all the respondents were unaware of the soils and substrates standards. 79 percent of the vegetable growers had partial awareness of GAP standards for harvesting and handling vegetables, while there were mixed findings for awareness of animal and pest control GAP standards with partial knowledge by 46 percent of respondents, followed at 34 percent by those completely unaware. Waghmod et al., (2020) have reported similar findings.

The findings revealed that two-thirds of the vegetable growers were unaware of GAP standards for worker health and safety, and almost half the respondents (49\%) were partially aware of the standards for storage and transport, while 41 percent were completely unaware.

The majority of the vegetable growers (91\%) were unaware of GAP waste management standards and all the vegetable growers were unaware of GAP standards of worker training. These findings are confirmed by Rochelle et al., (2014) and Jackson et al., (2007).

\section{Determinants of awareness to Good Agricultural Practices (GAP)}

To find out the relative contribution of independent variables on farmers' awareness towards implementation of GAP, multiple regression analyses were computed and presented in Table 4. The variables statistically significantly predicted awareness in site history, planting material, chemicals, integrated pest management, soils and substrates, animal and pests, storage and transport, worker health and safety, and waste management among the vegetable farmers. Five variables, education level, operational land, land leased, training and income added statistically significantly to the prediction, $\mathrm{p}<.05$. 
Table.1 Smallholder vegetable growers' socioeconomic characteristics

\begin{tabular}{|c|c|c|c|}
\hline Socioeconomic characteristic & Category & $f$ & or \\
\hline \multirow{3}{*}{ Age } & Young (18-30) & 24 & 24.0 \\
\hline & Middle (31-50) & 75 & 75.0 \\
\hline & Old $(>50)$ & 1 & 1.0 \\
\hline \multirow[t]{7}{*}{ Level of Education } & Illiterate & 6 & 6.0 \\
\hline & Primary & - & - \\
\hline & Middle & 9 & 9.0 \\
\hline & Matric & 19 & 19.0 \\
\hline & Secondary & 47 & 47.0 \\
\hline & Graduate & 18 & 18.0 \\
\hline & Post Graduate & 1 & 1.0 \\
\hline \multirow[t]{3}{*}{ Vegetable growing experience } & Low $(<10$ years $)$ & 72 & 72.0 \\
\hline & Medium (10-20 years) & 27 & 27.0 \\
\hline & High (> 20 years) & 1 & 1.0 \\
\hline \multirow{5}{*}{ Operational Land holdings } & Marginal $(<2.5)$ & 64 & 64.0 \\
\hline & Small (2.5-5) & 36 & 36.0 \\
\hline & Semi-medium (5-10) & - & - \\
\hline & Medium (10 -25) & - & - \\
\hline & Large (>25) & - & \\
\hline \multirow[t]{5}{*}{ Land leased for vegetables } & Marginal $(<2.5)$ & 83 & 83.0 \\
\hline & Small (2.5-5) & 16 & 16.0 \\
\hline & Semi-medium (5-10) & 1 & 1.0 \\
\hline & Medium (10 -25) & - & - \\
\hline & Large (>25) & - & - \\
\hline \multirow[t]{3}{*}{ Annual income } & Low (<4 lakhs) & 4 & 4.0 \\
\hline & Medium (4-7 lakhs) & 14 & 14.0 \\
\hline & High (>7 lakhs) & 82 & 82.0 \\
\hline Training in GAP & Yes & 4 & 4.0 \\
\hline
\end{tabular}

\footnotetext{
* Source: Field survey, 2021
} 
Table.2 Distribution of vegetable growers' according to awareness of GAP

\begin{tabular}{|c|c|c|c|}
\hline \multirow[t]{2}{*}{ S.No. } & \multirow[t]{2}{*}{ GAP protocols } & \multirow[t]{2}{*}{ Awareness Level } & Punjab \\
\hline & & & $f(\%)$ \\
\hline \multirow[t]{3}{*}{1} & \multirow[t]{3}{*}{ Site History } & none & $3(3.0)$ \\
\hline & & partial & $67(67.0)$ \\
\hline & & High & $30(30.0)$ \\
\hline \multirow[t]{3}{*}{2} & \multirow[t]{3}{*}{ Planting Material } & none & $50(50.0)$ \\
\hline & & partial & $46(46.0)$ \\
\hline & & High & $4(4.0)$ \\
\hline \multirow[t]{3}{*}{3} & \multirow[t]{3}{*}{ Water Usage and Conservation } & none & $63(63.0)$ \\
\hline & & partial & $37(37.0)$ \\
\hline & & High & - \\
\hline \multirow[t]{3}{*}{4} & \multirow{3}{*}{ Fertilizer, Manures, Bio-Solids and Nutrition } & none & $31(31.0)$ \\
\hline & & partial & $59(59.0)$ \\
\hline & & High & $10(10.0)$ \\
\hline \multirow[t]{3}{*}{5} & \multirow{3}{*}{$\begin{array}{c}\text { Chemicals (plant protection and other } \\
\text { agrochemicals) }\end{array}$} & none & $68(68.0)$ \\
\hline & & partial & $28(28.0)$ \\
\hline & & High & $4(4.0)$ \\
\hline \multirow[t]{3}{*}{6} & \multirow[t]{3}{*}{ Integrated Pest Management } & none & $30(30.0)$ \\
\hline & & partial & $6(6.0)$ \\
\hline & & High & $64(64.0)$ \\
\hline \multirow[t]{3}{*}{7} & \multirow[t]{3}{*}{ Soils and Substrates } & none & $100(100.0)$ \\
\hline & & partial & - \\
\hline & & High & - \\
\hline \multirow[t]{3}{*}{8} & \multirow[t]{3}{*}{ Harvesting and handling vegetables } & none & $2(2.0)$ \\
\hline & & partial & $79(79.0)$ \\
\hline & & High & 19(19.0) \\
\hline \multirow[t]{3}{*}{9} & \multirow[t]{3}{*}{ Animal and pest control } & none & $34(34.0)$ \\
\hline & & partial & $46(46.0)$ \\
\hline & & High & 20(20.0) \\
\hline \multirow[t]{3}{*}{10} & \multirow[t]{3}{*}{ Worker health and safety } & none & $64(64.0)$ \\
\hline & & partial & $36(36.0)$ \\
\hline & & High & - \\
\hline \multirow[t]{3}{*}{11} & \multirow[t]{3}{*}{ Storage and transport } & none & $41(41.0)$ \\
\hline & & partial & $49(49.0)$ \\
\hline & & High & $10(10.0)$ \\
\hline \multirow[t]{3}{*}{12} & \multirow[t]{3}{*}{ Waste management } & none & $91(91.0)$ \\
\hline & & partial & $9(9.0)$ \\
\hline & & High & - \\
\hline 13 & Training & none & $100(100.0)$ \\
\hline & & partial & - \\
\hline & & High & - \\
\hline
\end{tabular}

* Source: Field survey, 2021 
Table.3 Multiple regression of awareness on socio-economic characteristics

\begin{tabular}{|c|c|c|c|}
\hline Standards & $\mathbf{R}^{2}$ & d.f. & F, $\boldsymbol{\alpha}$ \\
\hline Site History & .239 & $(8,91)$ & $3.564^{* *}$ \\
\hline Planting Material & .280 & $(8,91)$ & $4.424^{* *}$ \\
\hline Water Usage & .094 & $(8,91)$ & $1.180, .320$ \\
\hline Fertilizers, Manures, and Bio-solids & .129 & $(8,91)$ & $1.686, .112$ \\
\hline Chemicals & .274 & $(8,91)$ & $4.285^{* *}$ \\
\hline Integrated Pest Management & .187 & $(8,91)$ & $2.612^{* *}$ \\
\hline Soils and substrates & .167 & $(8,91)$ & $2.284^{* *}$ \\
\hline Harvesting and Handling & .140 & $(8,91)$ & $1.851, .078$ \\
\hline Animal and Pest Control & .190 & $(8,91)$ & $2.671^{*}$ \\
\hline Worker Health and Safety & .343 & $(8,91)$ & $5.942^{* *}$ \\
\hline Storage and Transport & .237 & $(8,91)$ & $3.538^{* *}$ \\
\hline Waste Management & .197 & $(8,91)$ & $2.797^{*}$ \\
\hline Worker Training & .133 & $(8,91)$ & $1.748, .098$ \\
\hline
\end{tabular}

$*$ for significant at 0.05 level of significance $* *$ for significant at $0.001 \%$ level of significance

The results show a slightly below-average awareness of Good Agricultural Practices (GAPs) among the vegetable growers. Prior information is thus necessary for the adoption of any agricultural technology. The findings also suggest that emphasis on education and training affects the awareness of GAP. In this context, emphasis should be on training and capacity building of vegetable growers regarding GAP. Government should prioritize GAP-related programs for the farmers to benefit in terms of quality and quantity of produce, income and simultaneously maintain a harmonious relationship with the environment. Motivation for GAP adoption by the farmers can be strengthened by focusing on the benefits they can achieve, especially on higher market access and premium price on their produce.

\section{Acknowledgement}

This paper is a part of Ph.D. research work of the author. The author's duly acknowledge Indian Council of Agricultural Research for financial assistance under the ICAR full-term doctoral fellowship scheme. The authors are also grateful for the cooperation and hospitality of the vegetable farmers in Punjab State, India.

\section{References}

Adebayo, S. A. and O. I. Oladele. 2012. A review of selected theories and their applications to information seeking behaviour and adoption of organic agricultural practices by farmers. Life Science Journal. 9: 63-66. http://www.lifesciencesite.com.

Asian Productivity Organization. 2016. Manual on Good Agricultural Practices (GAP).

Arati J.; K. Dharmendra and T. Ujjal. 2019. Determinants of awareness of good agricultural practices (GAP) among banana growers in Chitwan, Nepal. Journal of Agriculture and Food Research, https://doi.org:10.1101/2020.06.12.148 551

Arpita, M.; M. Tanu; S. Goyal; A. K. Miglani; R. V. Anuradha and R. Ronjini. 2019. SPS barriers to India's agriculture 
export learning from the EU experiences in SPS and food safety standards. New Delhi: Indian Council for Research on International Economic Relations (ICRIER).

Bernier, Q.; R. S. Meinzen-Dick; P. M. Kristjanson; E. Haglund; C. Kovarik; E. Bryan and S. Silvestri.201). Gender and institutional aspects of climatesmart agricultural practices: Evidence from Kenya.

David, S.; and C. Asamoah. 2011. Farmer knowledge as an early indicator of IPM adoption: A case study from cocoa farmer field schools in Ghana. Journal of Sustainable Development in Africa. 13: 213-224.

Chaturvedi, S and G. Nagpal. 2003. WTO and product-related environmental standards: emerging issues and policy options. Economic and Political Weekly.

Chaudhary, V.; S. Satheesh Kumar. 2018. Assessment of groundwater quality for drinking and irrigation purposes in arid areas of Rajasthan, India. Applied Water

Science, 8: 218.https://doi.org/10.1007/ s13201-018-0865-9

Cherotich, C. 2021 Behavioural intentions of vegetable growers for adoption of Good Agricultural Practices (GAP) in Punjab, India and Nakuru, Kenya. Ph.D. Dissertation. Punjab Agricultural University. Ludhiana.

Jackson, C.; D. Archer; R. GoodrichSchneider; R. Gravani; E. Bihn and K. Schneider. 2007. Determining the effect of Good Agricultural Practices awareness on implementation: A multi-state survey. Food Protection Trends, 27: 684-693.

Knox, J. W.; M. G. Kay and E. K. Weatherhead. 2012. Water regulation, crop production and agricultural water management - understanding farmer perspectives on irrigation efficiency. Agricultural Water Management, 108: 3-

8.https://doi.org/10.1016/j.agwat.2011. 06.007

Luquet, D.; A. Vidal; M. Smith and J. Dauzat. 2005. 'More crop per drop': How to make it acceptable for farmers? Agricultural Water Management, 76: 108-119. https://doi.org/10.1016/j.agwat.2005.0 1.011

Mohammad, I. K.; B. Sharad and M. Gaurav. 2020. Socio-economic profile of vegetable growers under horticulture based module of farmer first project in Balaghat (M.P.), India. International Journal of Current Microbiology and Applied Sciences, 9: 32523257.https://doi.org/10.20546/ijcmas.2 020.903 .372

Muatha, I. T.; D. J. Otieno and R. A. Nyikal. 2016. Factors influencing smallholder farmers' awareness of agricultural extension devolution in Kenya: a binary logit analysis. Retrieved from https://ageconsearch.umn.edu/record/2 46283/files/6/ Kenya.pdf.

Nair, R and S. Barche. 2014. Protected cultivation of vegetables -present status and future prospects in India: Present status and future in India. Indian Journal of Applied Research, 4: 245-

247.https://doi.org/:10.15373/2249555 $\mathrm{X}$

Reeves, M and K. Schafer. 2003. Greater risks, fewer rights: U. S. farm workers and pesticides. International Journal of Occupational and Environmental Health, $\quad 9:$ 30-39. https://doi.org/10.1179/107735203800 328858

Rehman, F. 2013. Farmers' awareness and application of improved water management practices. International 
Journal of Advanced Research in Management and Social Sciences, 2: 20-27.

Rochele, R.; R. L. Márcia; M. D. Cheila; T. H. Claudia; J. Liesbeth; U. Mieke; J. B. Renar and C. T. Eduardo. 2014. Microbiological contamination linked to implementation of good agricultural practices in the production of organic lettuce in Southern Brazil.Food Control, $\quad$ 42: 152-164. https://doi.org/10.1016/j.foodcont.2014 .01 .043

Samra, N and P. Kataria. 2014. Profitability analysis of vegetable growers vis-a-vis farm size in Punjab. Journal of Agricultural Sciences, 5: 11-17. https://doi.org/10.1080/09766898.2014 .11884708 .

Sandesh, T.; R. Neha; B. Rakshya; N. Anjal and A. Sashila. 2020. Rooftop gardening as a need for sustainable urban farming: A case of Kathmandu, Nepal. International Journal of Applied Sciences and Biotechnology 8: 241-246. https://doi.org/0000-00020292-3779

Singh, T. 2017. Issues and Challenges of Indian Agriculture. International Journal of Research in Social Sciences, 7: 75-78.

Waghmod, Y. J.; D. P. Hardikar and P. C. Haldavanekar. 2020. Adoption of Good Agriculture Practices by mango growers. International Journal of Current Microbiology and Applied Sciences, $\quad$ 91: 86-203. https://doi.org/10.20546/ijcmas.2020.9 04.024

\section{How to cite this article:}

Carloyne Cherotich and Manmeet Kaur. 2021. Determinants of Awareness of Good Agricultural Practices (GAP) Among Vegetable Growers in Punjab, India. Int.J.Curr.Microbiol.App.Sci. 10(11): 218-225. doi: https://doi.org/10.20546/ijcmas.2021.1011.025 